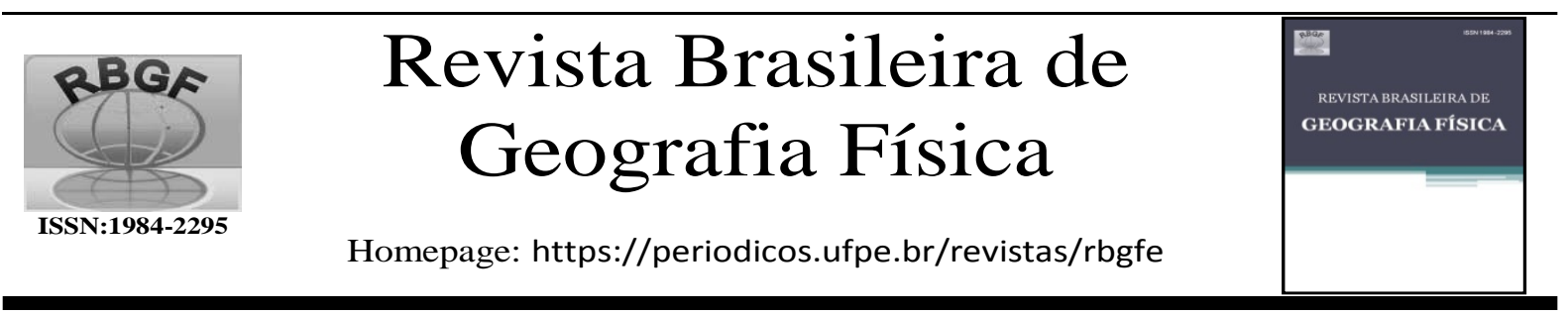

\title{
Assessment of CMIP6 Simulations over Tropical South America
}

\author{
Cássia Gabriele Dias ${ }^{1}$ e Michelle Simões Reboita ${ }^{2}$
}

\begin{abstract}
${ }^{1}$ Mestre em Meio Ambiente e Recursos Hídricos, bolsista, Universidade Federal de Itajubá, ${ }^{2}$ Professora Doutora do Instituto de Recursos Naturais (IRN) - Universidade Federal de Itajubá, Av. BPS, 1303, Bairro Pinheirinho, Itajubá, MG, Brasil, Autor correspondente E-mail: cassia_dias08@hotmail.com
\end{abstract}

Artigo recebido em 26/02/2021 e aceito em 04/05/2021

\begin{abstract}
A B S T R A C T
This study assesses the performance of 46 global climate models of the Coupled Model Intercomparison Project (Phase 6) - CMIP6 and selects better models in simulating the precipitation and the air temperature at 2 meters height climatology over tropical South America (SA) during the historical period (1996-2014). For this reason, some statistical measures are computed. A great number of models have a small bias when compared with observation, however, a lot of them have a poor performance in terms of the Willmott agreement index, which indicates a low performance in representing the temporal variability. Among the 46 models, E3SM-1-0, EC-Earth3, EC-Earth3-AerChem, EC-Earth3-Veg, IPSL-CM6ALR, MPI-ESM1-2-LR and TaiESM1 have a better performance in reproducing SA climate. When the ensemble of the 7 models is compared with that 46 models, there is a reduction in the bias of the variables under study in some sectors of the SA. This indicates that the use of 7 models is enough for application in other studies.

Keywords: CMIP6; tropical South America; validation; atmospheric variables
\end{abstract}

\section{Avaliação de Simulações do CMIP6 sobre a América do Sul Tropical}

\section{R E S U M O}

Este estudo avalia o desempenho de 46 modelos climáticos globais do Coupled Model Intercomparison Project (Fase 6) - CMIP6 e seleciona os que melhor simulam a climatologia da precipitação e temperatura do ar a 2 metros de altura sobre a América do Sul (AS) tropical durante o período histórico (1996-2014). Para isso, são calculadas algumas medidas estatísticas. Enquanto a maioria dos modelos apresenta um viés aceitável quando comparados com a observação, muitos deles mostram uma baixa performance em termos do índice de concordância de Willmott, o que indica menor habilidade em representar a variabilidade temporal. Entre os 46 modelos, E3SM-1-0, EC-Earth3, EC-Earth3-AerChem, EC-Earth3Veg, IPSL-CM6A-LR, MPI-ESM1-2-LR e TaiESM1 têm maior habilidade em reproduzir o clima da AS. Quando o ensemble desses 7 modelos é comparado com composto de 46 modelos, apresenta redução no viés das variáveis em estudo em alguns setores da AS. Isso indica, que a utilização de 7 modelos é suficiente para aplicação em outros estudos.

Palavras-chave: CMIP6; América do Sul Tropical; validação; variáveis atmosféricas

\section{Introduction}

The need to systematize the analyses of the coupled ocean and atmosphere models from multiple climate modeling centers lead to the World Climate Research Program (WCRP) to create the Coupled Model Intercomparison Project (CMIP) in September 1995 (Eyring et al., 2016; Carlson et al., 2017). Then, CMIP has developed climate model experiment protocols to ensure model output availability to a wide research community (Carlson et al., 2017). Currently, CMIP is in the sixth phase (CMIP6) and its outputs are free available by the Earth System Grid Federation (ESGF).
Global climate models (GCMs) of CMIP have provided useful information to the Intergovernmental Panel on Climate Change (IPCC) reports over the years. The projections are performed by different research groups and freely available for everyone on a webpage. Then, the researchers produce scientific papers with these data and IPCC collects and synthesizes them. So, it is published in IPCC reports. The last report published was IPCC-AR5 in 2013. Moreover, CMIP outputs have been used as initial and boundary conditions in regional climate models 
(RCMs; Elguindi et al., 2014; Gutowski Jr. et al., 2016; Ambrizzi et al., 2018).

Different studies have assessed the reliability of the simulations for the present climate over South America (Gulizia and Camilloni, 2014; Tian and Dong, 2020, Vasconcellos et al., 2020) while others focus on the climate projections (Blázquez and Nuñez, 2013; Torres and Marengo, 2013; Llopart, Reboita and da Rocha, 2020). In general, they show that the models represent the main characteristics of the South American climate in terms of precipitation and air temperature.

A basic requirement in studies using the GCMs of CMIP is to mention why certain models were selected for the study. In this sense, the GCMs performance needs to be evaluated before applying them, such as in dynamical downscaling. In this context, the purpose of this study is to identify the GCMs from CMIP6 that better represent the South American tropical climate in terms of precipitation and air temperature.

\section{Methodology}

Data

Simulations of precipitation and air temperature at 2 meters height of 46 CMIP6-GCMs (Eyring et al., 2016) for the historical period (December 1996 - November 2014) are evaluated (model names are presented in Table 1). The simulations were obtained from The Earth System Grid Federation (ESGF; platform (https://esgfnode.llnl.gov/search/cmip6/) and, posteriorly, the area of tropical South America $\left(75^{\circ} \mathrm{W}-35^{\circ} \mathrm{W}\right.$ and $35^{\circ} \mathrm{S}-0^{\circ}$ ) was selected in the GCMs outputs.

Daily precipitation analysis with a horizontal resolution of one degree from Global Precipitation Climatology Project Version 1.2 (GPCP; Huffman et al., 2001) was considered as observed data and downloaded from ftp://ftp.cgd.ucar.edu/archive/PRECIP/. For air temperature validation, ERA5 reanalysis (Hersbach and Dee, 2016) from the European Centre for Medium-Range Weather Forecasts (ECMWF), with $0.25^{\circ}$ of the horizontal resolution was used. The studied period is limited between 1996 and 2014 due to the GPCP precipitation availability.

All datasets were interpolated to one degree of grid space with the bi-linear technique (Jones, 1999; Chen and Knutson, 2008; Santos, Martins and Torres, 2017) before the analyses. This procedure allows us to compute the grid point differences between simulation and observation and represent them spatially.

\section{Statistical Analyses}

a) Spatial representation: The first step of this study is to present the seasonal and annual maps of precipitation and air temperature at $2 \mathrm{~m}$ for the observation and the ensemble (average of the $46 \mathrm{GCMs}$ ) and the spatial bias between them (eq. 1).

$$
\text { Bias }=\mathrm{P}-\mathrm{O} \text { (eq. 1) }
$$

in that $\mathrm{P}$ and $\mathrm{O}$ are, respectively, the CMIP6-GCMs ensemble and the observation.

We also computed the spatial correlation (r) (eq. 2) and the bias of the seasonal average of ensemble and observations. The obtained values are included in the title of the figures.

$$
r=\frac{\sum_{i=1}^{n}(O i-O)(P i-P)}{\sqrt{\sum_{i=1}^{n}(P i-P)^{2} \sum_{i=1}^{n}(O i-O)^{2}}}(\text { eq. } 2)
$$

being $\mathrm{n}$ is the number of years under study, Pi and Oi, respectively, each simulated and observed value. Correlation can range from +1 to -1 , where +1 indicates a perfect positive relationship, -1 indicates a perfect negative relationship, and 0 indicates no relationship exists. Correlation values from 0.91 to $1.0(-0.91$ to -1.0$)$ indicate very high correlation; from 0.71 to 0.9 (- 0.71 to -0.9 ) a high correlation; from 0.51 to 0.7 (-0.51 to -0.7$)$ moderate correlation; from 0.31 to 0.5 ( -0.31 to 0.5 ) a weak correlation; from 0.0 to 0.3 (0.0 to -0.3 ) a very weak correlation (Hinkle et al., 2003).

b) Selecting better models: The second step of the study is to compute the seasonal and annual bias of the precipitation and air temperature for the box of tropical South America $\left(75^{\circ} \mathrm{W}-35^{\circ} \mathrm{W}\right.$ and $35^{\circ} \mathrm{S}$ $-0^{\circ}$ ) considering each individual CMIP6-GCM. Here we get a single value for the bias and it is represented visually through a heatmap (Metsalu and Vilo, 2015; Yi, 2019). The same is done for the Willmott agreement index (d; eq. 3; Willmott et al., 2011; Reboita et al., 2018):

$$
d=1-\frac{\sum_{i=1}^{n}(P i-O i)^{2}}{\sum_{i=1}^{n}(|P i-O|+|O i-O|)^{2}}(\text { eq. 3) }
$$

in that $\mathrm{Pi}$ and $\mathrm{Oi}$ are, respectively, each simulated and observed value while $\mathrm{P}$ and $\mathrm{O}$ are the averages of the time series, simulated and observed, respectively. The agreement index ranges from 0 to 1 where 1 indicates the perfect agreement between simulation and observation.

Bias and $\mathrm{d}$ for seasonal and annual periods are presented in heatmaps. The seasons are defined 
as DJF (December-January-February), MAM (March-April-May), JJA (June-July-August) and SON (September-October-November).

The analysis of these statistics allows us to define what are the models that better represent the seasonal climatology of precipitation and air temperature over South America. So, these models are selected and a new ensemble is performed.

Table 1 Horizontal resolution (longitude x latitude) and references of each CMIP6-GCM.

\begin{tabular}{|c|c|c|c|c|c|}
\hline Model & lon $\times$ lat & References & Model & lon $\times$ lat & References \\
\hline ACCESS-CM2 & $192 \times 144$ & Dix et al. (2019) & $\begin{array}{l}\text { FGOALS-f3- } \\
\text { L }\end{array}$ & $288 \times 180$ & Yu (2019) \\
\hline $\begin{array}{l}\text { ACCESS-ESM1- } \\
5\end{array}$ & $192 \times 145$ & Ziehn et al. (2019) & FGOALS-g3 & $180 \times 80$ & Li (2019) \\
\hline $\begin{array}{c}\text { AWI-CM-1-1- } \\
\text { MR }\end{array}$ & $384 \times 192$ & Semmler et al. (2018) & FIO-ESM-2-0 & $288 \times 192$ & Song et al. (2019) \\
\hline $\begin{array}{l}\text { AWI-ESM-1-1- } \\
\text { LR }\end{array}$ & $192 \times 96$ & Danek et al. (2020) & GFDL-ESM4 & $288 \times 180$ & Krasting et al. (2018) \\
\hline BCC-CSM2-MR & $320 \times 160$ & Wu et al. (2018) & GISS-E2-1-G & $144 \times 90$ & NASA-GISS (2018) \\
\hline BCC-ESM1 & $128 \times 64$ & Zhang et al. (2018) & GISS-E2-1-H & $144 \times 90$ & NASA-GISS (2019) \\
\hline CAMS-CSM1-0 & $320 \times 160$ & Rong (2019) & IITM-ESM & $192 \times 94$ & $\begin{array}{c}\text { Raghavan and Panickal } \\
\text { (2019) }\end{array}$ \\
\hline CanESM5 & $128 \times 64$ & Swart et al. (2019) & INM-CM4-8 & $180 \times 120$ & Volodin et al. (2019a) \\
\hline CAS-ESM2-0 & $256 \times 128$ & Danabasoglu (2019b) & INM-CM5-0 & $180 \times 120$ & Volodin et al. (2019b) \\
\hline CESM2 & $288 \times 192$ & Danabasoglu (2019a) & $\begin{array}{l}\text { IPSL-CM6A- } \\
\text { LR } \\
\end{array}$ & $144 \times 143$ & Boucher et al. (2018) \\
\hline CESM2-FV2 & $144 \times 96$ & Danabasoglu (2019d) & KACE-1-0-G & $192 \times 144$ & Byun et al. (2019) \\
\hline $\begin{array}{l}\text { CESM2- } \\
\text { WACCM }\end{array}$ & $288 \times 192$ & Danabasoglu (2019c) & $\begin{array}{c}\text { MCM-UA-1- } \\
0\end{array}$ & $96 \times 80$ & Stouffer (2019) \\
\hline $\begin{array}{c}\text { CESM2- } \\
\text { WACCM-FV2 }\end{array}$ & $144 \times 96$ & Danabasoglu (2019e) & MIROC6 & $256 \times 128$ & $\begin{array}{c}\text { Tatebe and Watanabe } \\
\text { (2018) }\end{array}$ \\
\hline CIESM & $288 \times 192$ & Huang (2019) & $\begin{array}{c}\text { MPI-ESM-1- } \\
\text { 2-HAM } \\
\end{array}$ & $192 \times 96$ & Neubauer et al. (2019) \\
\hline $\begin{array}{c}\text { CMCC-CM2- } \\
\text { HR4 }\end{array}$ & $288 \times 192$ & $\begin{array}{l}\text { Scoccimarro, Bellucci } \\
\text { and Peano (2020) }\end{array}$ & $\begin{array}{l}\text { MPI-ESM1- } \\
\text { 2-HR }\end{array}$ & $384 \times 192$ & $\begin{array}{l}\text { Jungclaus, Bittner and } \\
\text { Wieners (2019) }\end{array}$ \\
\hline $\begin{array}{l}\text { CMCC-CM2- } \\
\text { SR5 } \\
\end{array}$ & $288 \times 192$ & $\begin{array}{c}\text { Lovato and Peano } \\
(2020)\end{array}$ & $\begin{array}{l}\text { MPI-ESM1- } \\
\text { 2-LR } \\
\end{array}$ & $192 \times 96$ & Wieners et al. (2019) \\
\hline E3SM-1-0 & $360 \times 180$ & Bader et al. (2019a) & MRI-ESM2-0 & $320 \times 160$ & Yukimoto et al. (2019) \\
\hline E3SM-1-1 & $360 \times 180$ & Bader et al. (2019b) & NESM3 & $192 \times 96$ & Cao and Wang (2019) \\
\hline E3SM-1-1-ECA & $360 \times 180$ & Bader et al. (2020) & NorCPM1 & $144 \times 96$ & Bethke et al.(2019) \\
\hline EC-Earth3 & $512 \times 256$ & $\begin{array}{c}\text { EC-Earth Consortium } \\
(2019 b)\end{array}$ & $\begin{array}{l}\text { NorESM2- } \\
\text { LM } \\
\end{array}$ & $144 \times 96$ & Seland et al. (2019) \\
\hline $\begin{array}{l}\text { EC-Earth3- } \\
\text { AerChem }\end{array}$ & $512 \times 256$ & $\begin{array}{c}\text { EC-Earth Consortium } \\
(2020) \\
\end{array}$ & $\begin{array}{l}\text { NorESM2- } \\
\text { MM }\end{array}$ & $288 \times 192$ & Bentsen et al. (2019) \\
\hline EC-Earth3-Veg & $512 \times 256$ & $\begin{array}{c}\text { EC-Earth Consortium } \\
(2019 a)\end{array}$ & $\begin{array}{c}\text { SAM0- } \\
\text { UNICON }\end{array}$ & $288 \times 192$ & Park and Shin (2019) \\
\hline $\begin{array}{c}\text { EC-Earth3-Veg- } \\
\text { LR }\end{array}$ & $320 \times 160$ & $\begin{array}{c}\text { EC-Earth Consortium } \\
(2020) \\
\end{array}$ & TaiESM1 & $288 \times 192$ & Lee and Liang (2020) \\
\hline
\end{tabular}

\section{Results}

\section{Climatologies}

Figure 1 shows the seasonal and annual mean of precipitation of the observation (Figure 1 a-e) and 46 CMIP6-GCMs (Figure $1 \mathrm{f}-\mathrm{j}$ ) while Figure 2 shows the bias between them. These figures indicate that CMIP6-GCMs ensemble simulates well the temporal and spatial variability of the precipitation over tropical South America, but with some discrepancies in intensity. For example, during the rainy season of tropical South America, which is in DJF (Reboita et al., 2010; Marrafon and Reboita, 2020), CMIP6-GCMs ensemble displaces the wettest area over northwest Amazonia to east between north and northeast Brazilian regions. Moreover, in all seasons, GCMs are dryer over southern Brazil and wet over the Andes. In this last region, it can be a problem in the models due to the topography representation (Chou et al., 2014; Freire, de Freitas and Coelho, 2015).

Dias, C., G., Reboita"M.,S. 
The reported biases are also a common problem in regional climate models (Solman et al., 2013; Ambrizzi et al., 2018).

Vasconcellos et al. (2020) evaluated the DJF precipitation, in the historical period (19802005), over tropical South America simulated by 5 CMIP5 models (CCSM4, GFDL-ESM2G, GFDLESM2M, MIROC-ESM-CHEM and CAN-ESM2). As in our results (Figures $2 a-b$ ), the models overestimate the precipitation over northeast Brazil (2- $6 \mathrm{~mm} \mathrm{day}^{-1}$ ) and underestimate it in the north region. Tian and Dong (2020) compared the performance of CMIP3 (24 models in the period 1850-2000), CMIP5 (25 models in period of 18502005) and CMIP6 (26 models in the period of 2005-2014) in simulating the precipitation over the tropics. The three CMIP phases show a similar bias pattern over the tropics that is in agreement with the Figures $2 \mathrm{i}-\mathrm{j}$. The authors highlighted that CMIP5 decreases the precipitation underestimates over the north Brazil obtained in CMIP3 while CMIP6 shows improvements compared to CMIP5 in this same region.

In a summary, 46 CMIP6-GCMs ensemble simulates dryer conditions over the South Atlantic Convergence Zone (Figure $1 \mathrm{f}$ ), which is the rainy band from Amazonia to southeast Brazil in DJF (Silva et al., 2019; Pedro et al., 2020). However, comparing our results from that of CMIP3 and CMIP5 ensembles shown by Gulizia and Camilloni (2014), it is apparent that CMIP6 decreases the bias in the precipitation.

For the air temperature at $2 \mathrm{~m}$ (Figures 3 and 4), 46 CMIP6-GCMs ensemble has a good performance in representing the observation. Differences occur over the Amazonia and north of Argentina where the ensemble overestimates the air temperature. Dufresne et al. (2013) analyzed bias in the climatology of the annual near-surface temperature (with respect to the period 1961-1990) simulated by the IPSL-CM4 (CMIP3) and IPSLCM5A-LR, IPSL-CM5A-MR and IPSL-CM5BLR models from CMIP5. Except for the IPSL-CM4 model, which presented an overestimation in temperature for the entire region of the present study, the other models represented a similar pattern to that found in our Figures $4 \mathrm{i}$-j. However, those models have larger overestimates, of up to $4.5^{\circ} \mathrm{C}$, in the North and South of Brazil, and underestimation, of up to $2.5^{\circ} \mathrm{C}$, in the Northeast. $\mathrm{Wu}$ et al. (2019) evaluated the models BCCCSM1.1m (CMIP5) and BCC-CSM2-MR (CMIP6) for the period from 1986 to 2005 and also presented spatial pattern and values similar to the results of Dufresne et al. (2013).

GCMs Selection

Dias, C., G., Reboita"M.,S.
Working with simulations is not an easy task since it needs a lot of hard disk space to store the data and good resources for data processing. Then, instead of using all CMIP6 models in the studies for South America, we can select those that simulate better the climate. It helps to save computational resources. In this way, this section focuses on the evaluation and selection of the best models.

For the precipitation (Figure 5), the bias shows, in general, smaller values in DJF than in JJA. It is a good result since the DJF is the rainy season in tropical South America (Reboita et al., 2018; Llopart et al., 2020). EC-Earth3, EC-Earth3AerChem, EC-Earth3-Veg, EC-Earth3-Veg-LR, INM-CM4-8, INM-CM5-0, IPSL-CM6A-LR and TaiESM1 are the models with the lower biases. If we consider, for example, TaiESM1 model, it has a bias of 0.18 and $-0.43 \mathrm{~mm} \mathrm{day}^{-1}$ in DJF and JJA, respectively. These values represent an error of 3\% in the DJF climatology while $24 \%$ in JJA, and are in the error interval expected by the models for precipitation (Giorgi and Mearns, 1999). Regarding the agreement index for precipitation (Figure 6) in each season, the maximum values registered occur in MPI-ESM1-2-LR ( $\mathrm{d}=0.63$ in SON), NorESM2-MM ( $d=0.61$ in MAM), ECEarth3-Veg (d=0.60 in annual), IPSL-CM6A-LR (d=0.56 in DJF), IPSL-CM6A-LR and EC-Earth3Veg (0.49 in both in JJA).

For air temperature (Figure 7), E3SM-1-1, EC-Earth3, EC-Earth3-AerChem, EC-Earth3-Veg, IITM-ESM, and TaiESM1 show bias between -0.5 and $0.5^{\circ} \mathrm{C}$. It indicates the good performance of the models since has been accepted bias of up $2{ }^{\circ} \mathrm{C}$ in the simulated air temperature (Flato et al., 2013).

Although several models have a small seasonal bias, they show worse performance in terms of agreement index. It is associated with the fact that this index is more able to capture the variability of the time series than the bias (see equation in the methodology). For example, TaiESM1 has in DJF bias=0 and $d=0.58$ (Figure 7). It means that the year-to-year variability is not well represented. The maximum d obtained in Figure 8 is 0.73 for the annual period in EC-Earth3-Veg. This model also has a good seasonal performance. For example, $\mathrm{d}=0.63$ in JJA. MPI-ESM1-2-HR has also a good skill being $\mathrm{d}=0.68$ in MAM and SON. 
Revista Brasileira de Geografia Física v.14, n.03 (2021)1282-1295.
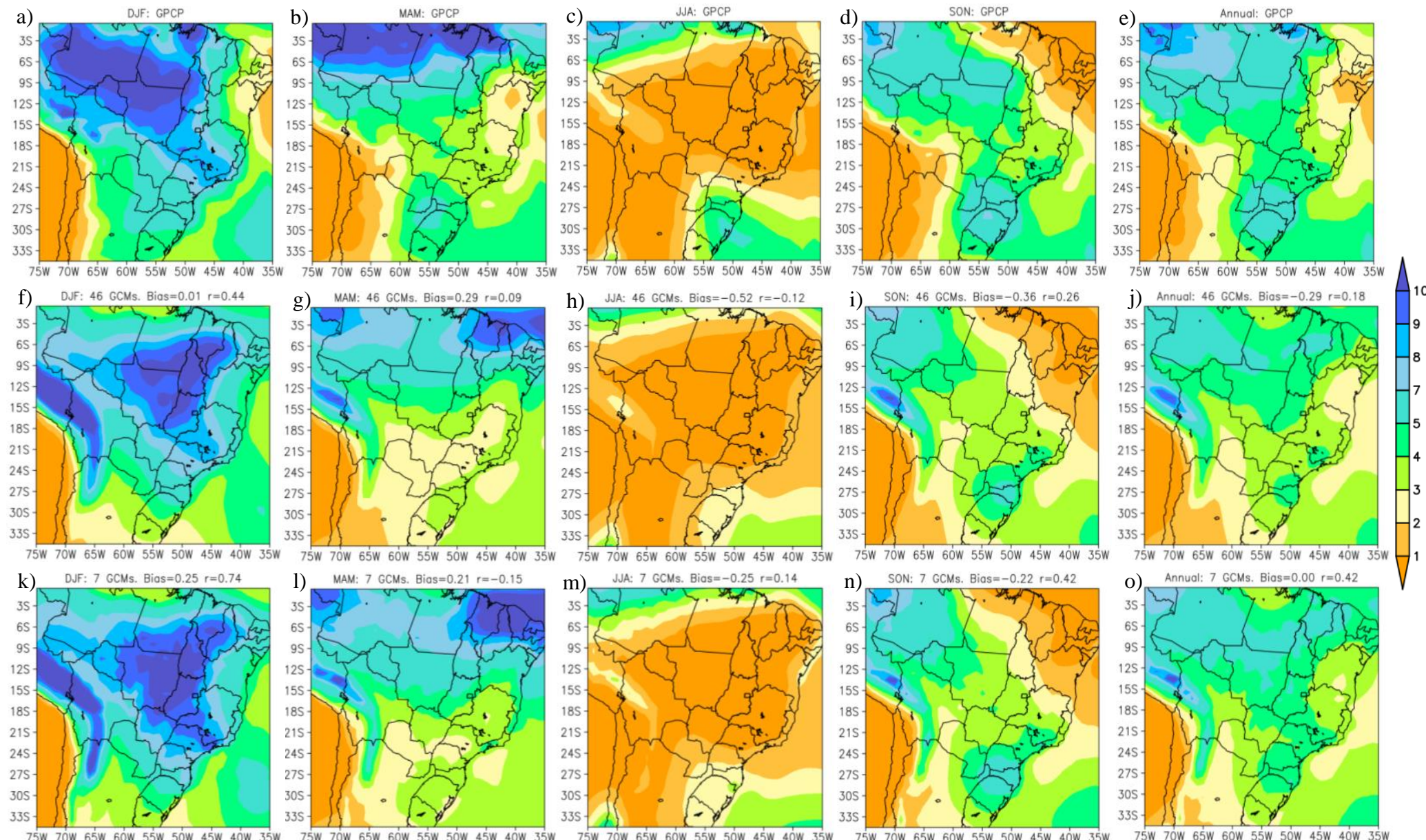

Figure 1 Seasonal and annual average of precipitation $\left(\mathrm{mm} \mathrm{day}^{-1}\right.$ ) for the period 1996-2014. The first line is GPCP. a) DJF, b) MAM, c) JJA, d) SON and e) annual. The second line is the 46 CMIP6-GCMs ensemble: f) DJF, g) MAM, h) JJA, i) SON and j) annual, and the third line is the 7 CMIP6-GCMs ensemble: $k$ ) DJF, l) MAM, m) JJA, n) SON and o) annual. 
Revista Brasileira de Geografia Física v.14, n.03 (2021)1282-1295.
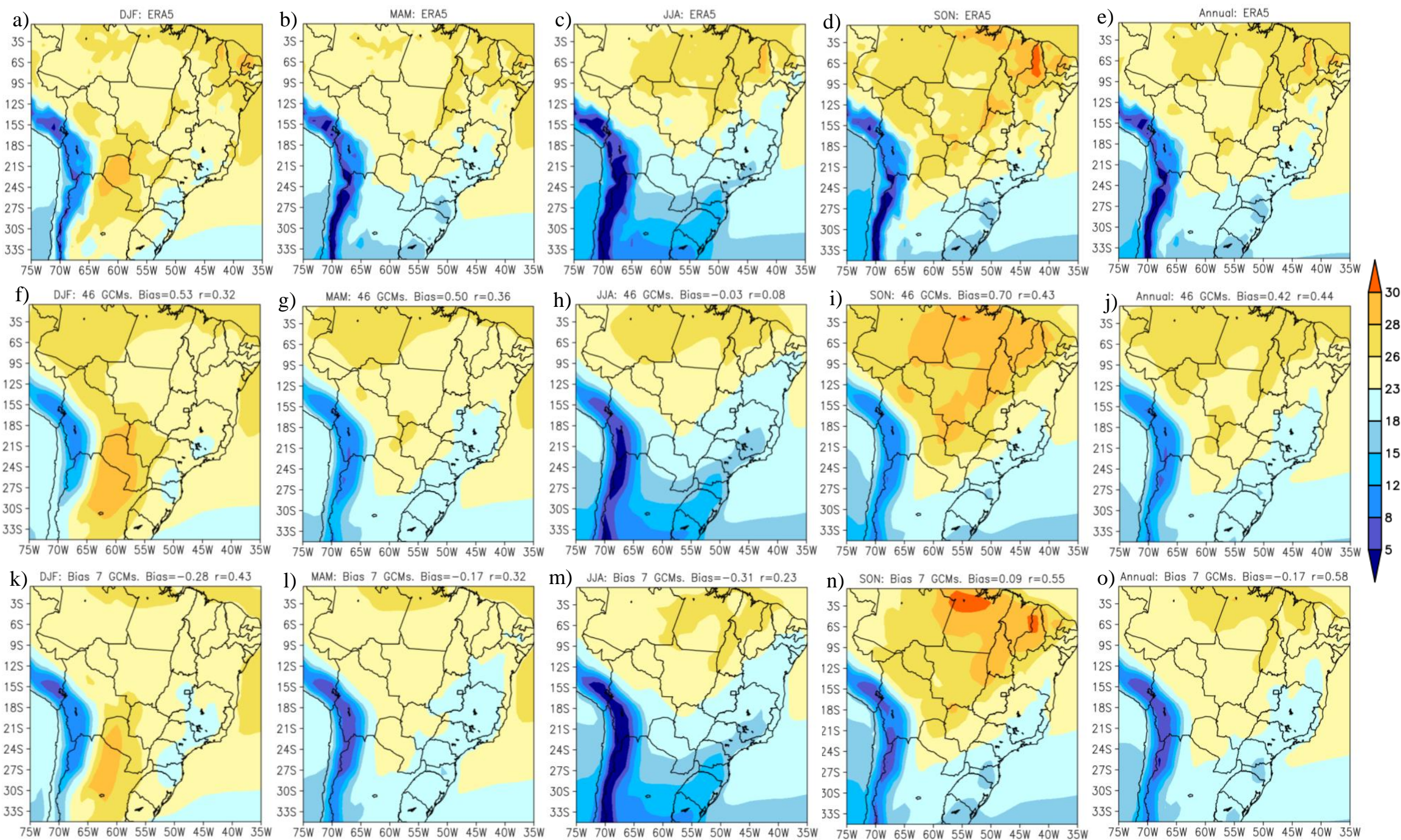

Figure 3 Similar to Figure 1 but to the air temperature at 2 meters height $\left({ }^{\circ} \mathrm{C}\right)$. 


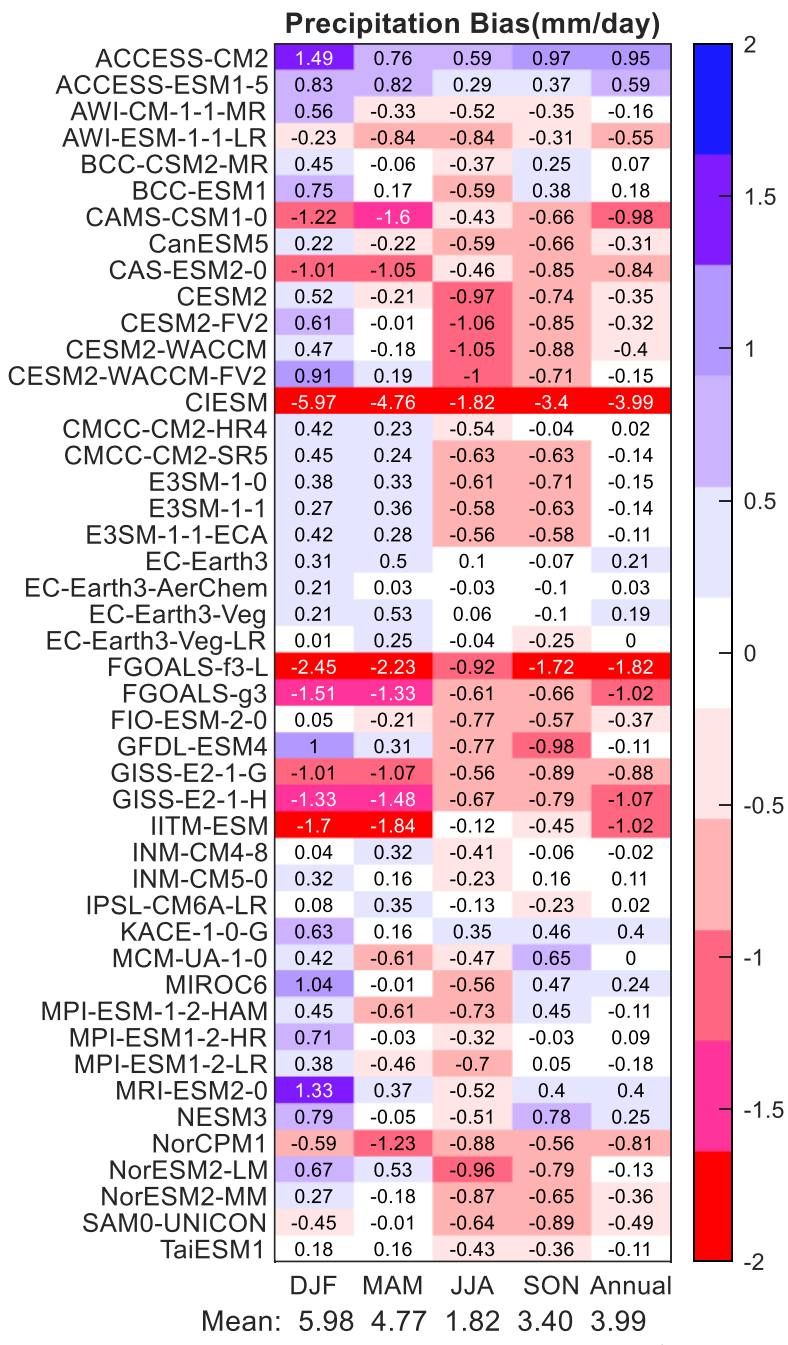

Figure 5 Bias of the precipitation $\left(\mathrm{mm} \mathrm{day}^{-1}\right)$ in the period 1996-2014.

For DJF, the maximum $\mathrm{d}(0.58)$ is obtained in TaiESM1.

Based on the precipitation and temperature statistical analysis, the models that show better performance for tropical South America are E3SM1-0, EC-Earth3, EC-Earth3-AerChem, EC-Earth3Veg, IPSL-CM6A-LR, MPI-ESM1-2-LR and TaiESM1.

\section{Comparison of the Ensembles}

In this section, we compared the performance of the ensembles with 46 and 7 members (Figures 1-4), hereafter called 46-GCMs and 7-GCMs, respectively. For precipitation, in DJF, the 7-GCMs (Figure 2b) presents better performance than 46-GCMs (Figure 2a) over Amazonas, Acre and Rio Grande do Sul. For MAM, 46-GCMs (Figure 2c) have a lower bias in the studied domain, except in Acre, Acre, Rondônia, Mato Grosso do Sul and São Paulo. In these regions, 7-GCMs ensemble presents a better performance (Figure 2d). In JJA, SON and annually, 7-GCMs (Figures 2f, $2 \mathrm{~h}$ and $2 \mathrm{j}$, respectively) ensemble, in general, shows lower bias in the whole domain compared to 46-GCMs (Figures 2e, 2g and 2i, respectively). Analyzing the spatial bias and correlation (Figures 1f-o), it can be noted that in most periods there is a better statistical representation of precipitation in the 7-GCMs. According to the correlation range (Hinkle et al., 2003), in 7-GCMs correlation is moderate in DJF (0.74; Figure 1k), very weak in MAM ( -0.15 ; Figure 11) and JJA (0.14; Figure $1 \mathrm{~m})$, and weak in SON (0.42; Figure 1n) and in the annual period (0.42; Figure 1o). For 46-GCMs, it is weak in DJF (0.44; Figure 1f) and very weak in MAM (0.09; Figure 1g), JJA (-0.12; Figure 1h), SON (0.26; Figure 1i) and in the annual period (0.18; Figure 1j). Regarding bias, 7-GCMs ensemble shows better results than 46-GCMs in all periods, except in DJF when 46-GCMs (Figure 1f) has bias of 0.01 and in 7-GCMs (Figure 1k) it is $0.25 \mathrm{~mm} \mathrm{day}^{-1}$.

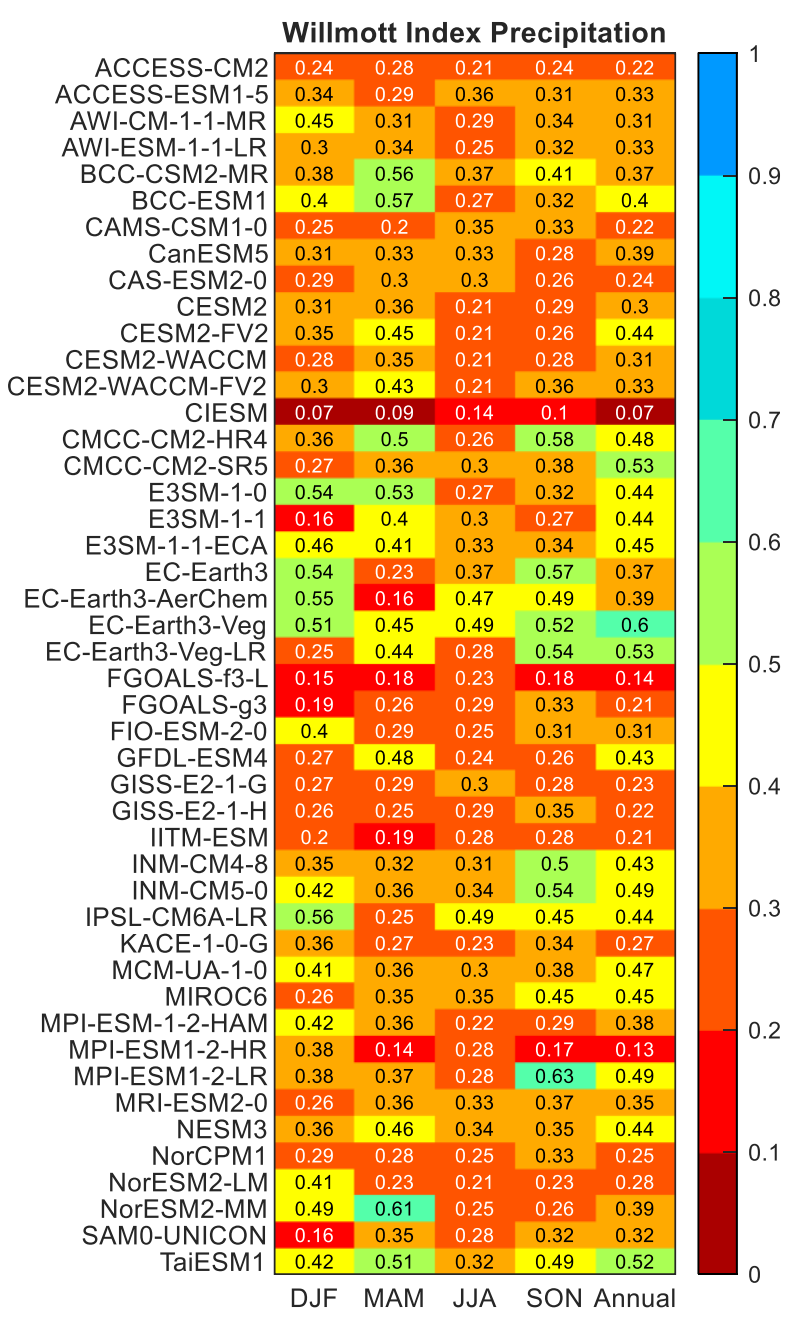

Figure 6 Willmott agreement index (d) of the precipitation $\left(\mathrm{mm} \mathrm{day}^{-1}\right)$ in the period 1996-2014. 


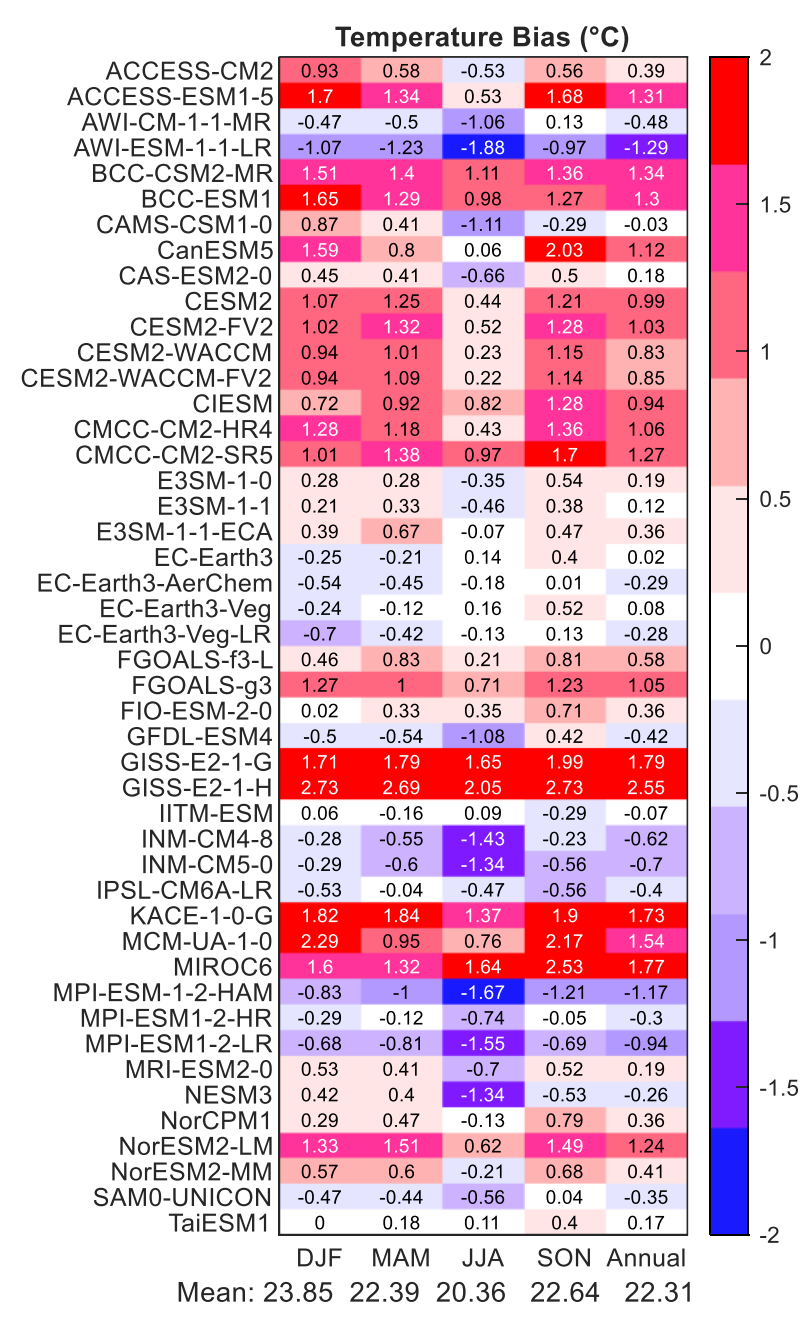

Figure 7 Bias of the air temperature at $2 \mathrm{~m}\left({ }^{\circ} \mathrm{C}\right)$ in the period 1996-2014.

Figure 4 shows the air temperature bias for 46-GCMs and 7-GCMs. In DJF, 7-GCMs ensemble simulates a lower bias over Mato Grosso, and in the south and north Brazilian regions compared to 46-GCMs (Figure 4b). In MAM, the ensembles (Figure $4 \mathrm{c}$ and $4 \mathrm{~d}$ ) show a similar pattern, however, the air temperature bias in 7-GCMsis is lower in the north and south Brazilian regions (Figure 4d) while it is lower in the northeast in the 46-GCMs (Figure 4c). In JJA the 7-GCMs (Fig.8e) has a poor performance over the northern region compared to 46-GCMs (Figure 4f); on the other hand, in SON (Figure 4h) and Annual 7-GCMs simulates smaller biases in almost the entire domain.

The spatial bias and correlation shows higher similarities with the observations for 7-GCMs than 46-GCMs in all periods under study. According to the correlation range (Hinkle et al., 2003), in 7GCMs correlation is weak in DJF (0.43; Figure 3k) and MAM (0.32; Figure 31), very weak in JJA $(0.23$; Figure $3 \mathrm{~m})$, and moderate in SON $(0.55$; Figure $3 n)$ and annual (0.58; Figure 3o). On the

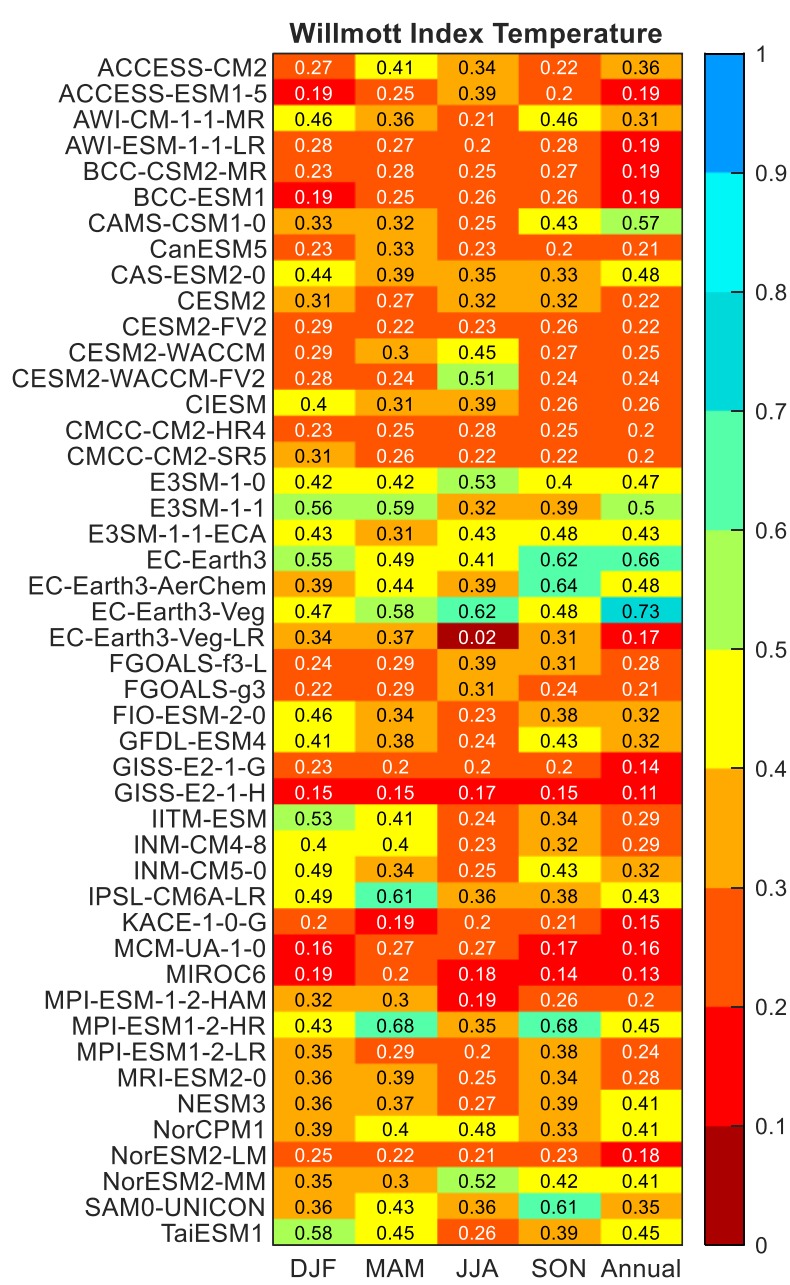

Figure 8 Willmott agreement index (d) of the air temperature at $2 \mathrm{~m}\left({ }^{\circ} \mathrm{C}\right)$ in the period $1996-2014$

other hand, for 46-GCMs it is weak in DJF (0.32; Figure 3f) and MAM (0.36; Figure 3g), very weak in JJA (0.08; Figure h), and weak in SON (0.43; Figure 3 i) and in annual period (0.44; Figure 3 j). Regarding bias, 7-GCMs ensemble has better results than 46-GCMs in all periods, except JJA (Figure 3m). In summary, 7-GCMs, in general, simulates a smoother bias than the 46-GCMs. 

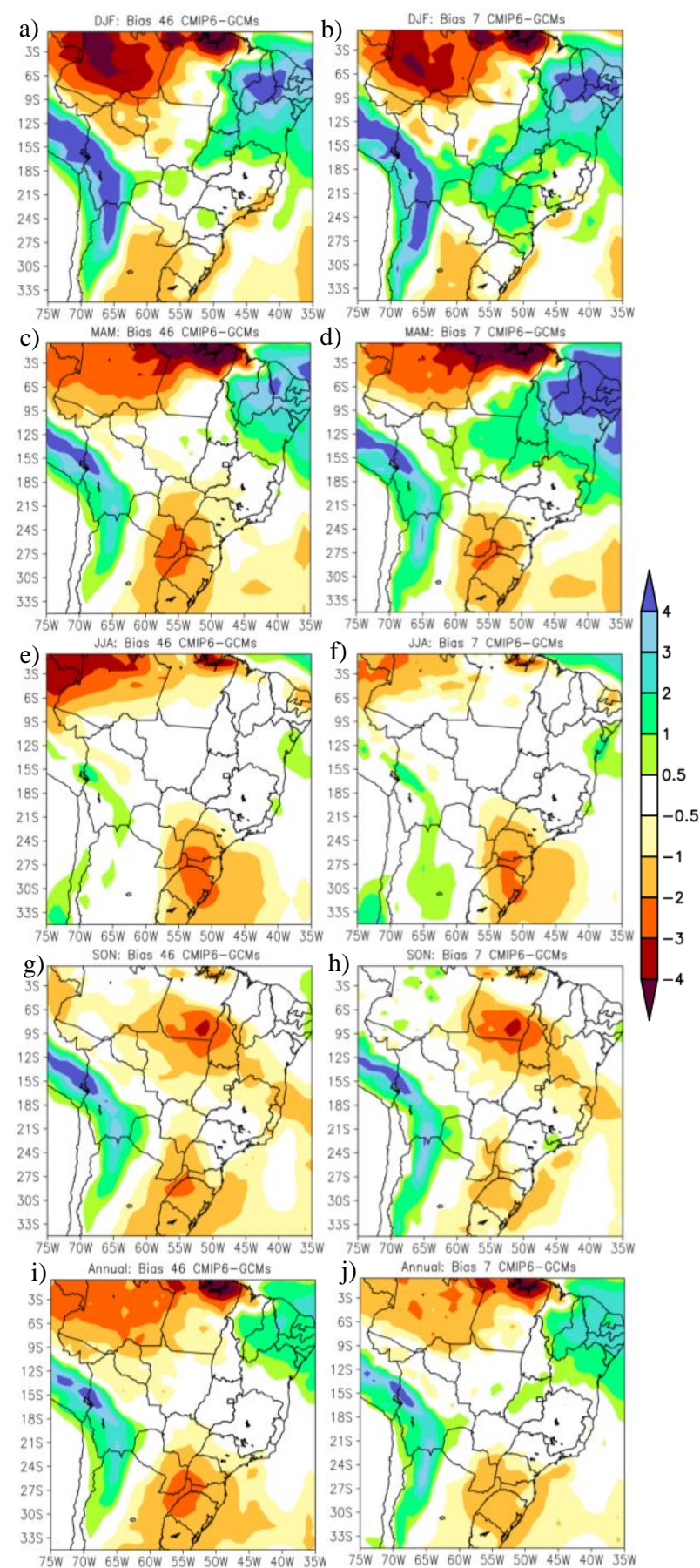

Figure 2 Seasonal and annual bias of precipitation $\left(\mathrm{mm} \mathrm{day}{ }^{-1}\right)$ for the period 1996-2014. The first column is 46 CMIP6-GCMs ensemble minus GPCP: a) DJF, c) MAM, e) JJA, g) SON and i) annual, and the second column is 7 CMIP6-

\section{Conclusions}

In this study, we obtained 46 CMIP6GCMs simulations of the historical period (19962014) for tropical South America. The purpose was to verify the performance of the 46 CMIP6-GCMs ensemble in reproducing the main features of the precipitation and air temperature climatologies over tropical South America. The second goal was to identify the better models in order to construct an ensemble with a reduced number of members
GCMs ensemble minus GPCP: b) DJF, d) MAM, f) JJA, h) SON and j) annual.
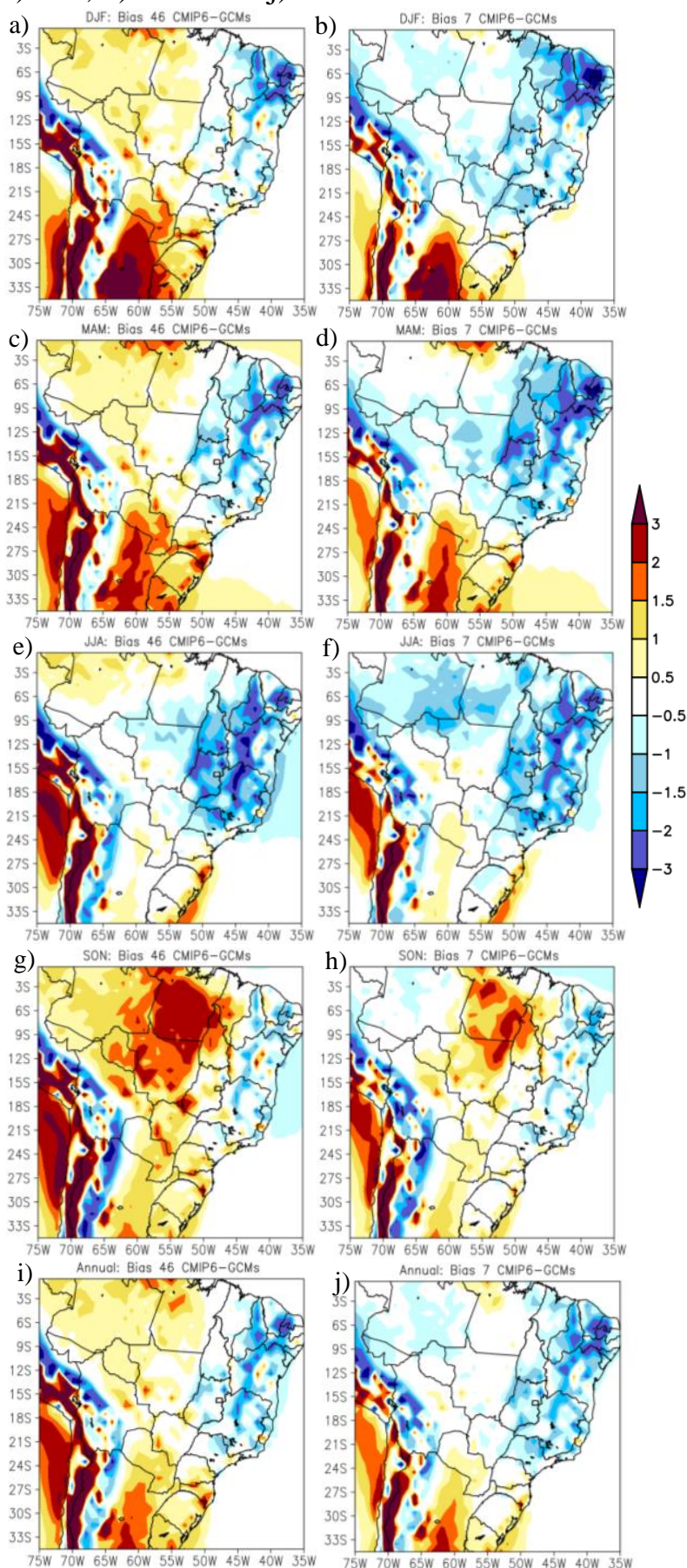

Figure 4 Similar to figure 2 but to air temperature at 2 meters height $\left({ }^{\circ} \mathrm{C}\right)$.

but with the same performance and/or better than that with 46 members.

For both precipitation and air temperature at $2 \mathrm{~m}$, in general, the bias values are acceptable, since according to Giorgi and Mearns (1999) for precipitation the acceptable error is in the range of 5 to $30 \%$, and according to Flato et al. (2013), the acceptable temperature error is up to $2{ }^{\circ} \mathrm{C}$.

Regarding the agreement index, which is a statistic more sensitive to the variability of the

Dias" C., G., Reboita"M.,S. 
data than the bias, there are no models with values close to 1 . It indicates that the models have a greater difficulty to capture the year-to-year variability. For precipitation, the models with better performance are: BCC-CSM2-MR, BCCESM1, CanESM5, CMCC-CM2-HR4, CMCCCM2-SR5, E3SM-1-0, E3SM-1-1 -ECA, ECEarth3, EC-Earth3-AerChem, EC-Earth3-Veg, INM-CM4-8, INN-CM5-0, IPSL-CM6A-LR, KACE-1-0-G, MCM-UA-1 -0, MPI-ESM1-2-LR and TaiESM1. Regarding the air temperature at 2 meters, the models that present better performance are: CAMS-CSM1-0, CAS-ESM2-0, E3SM-1-0, E3SM-1-1, E3SM-1-1-ECA, EC-Earth3, ECEarth3-AerChem, EC-Earth3-Veg, FIO-ESM-2-0, IITM-ESM, IPSL-CM6A-LR, MPI-ESM1-2-HR, NorESM2-MM, SAM0-UNICORN and TaiESM1.

In summary, for tropical South America studies, we recommend the models: E3SM-1-0, EC-Earth3, EC-Earth3-AerChem, EC-Earth3-Veg, IPSL-CM6A-LR, MPI-ESM1-2-LR and TaiESM1, since the individual analysis of these models show good statistical results when compared with the observation and the ensemble construct with them, in general, provided a smaller bias than the ensemble with 46 members.

\section{Acknowledgments}

The authors thank the CMIP6, ESGF, ECMWF and GPCP for the data used in this study and CNPq and FAPEMIG (Water-JPI) for financial support.

\section{References}

Ambrizzi, T., Reboita, M.S., da Rocha, R.P., Llopart, M., 2018. The state-of-the-art and fundamental aspects of regional climate modeling in South America. Annals of the New York Academy of Sciences 1436(1), 98-120. https://doi.org/10.1111/nyas.13932

Bader, D.C., Leung, R., Taylor, M., McCoy, R.B., 2019a. E3SM-Project E3SM1.0 model output prepared for CMIP6 CMIP historical. Version 20190913.Earth System Grid Federation. https://doi.org/10.22033/ESGF/CMIP6.4497

Bader, D.C., Leung, R., Taylor, M., McCoy, R.B., 2019b. E3SM-Project E3SM1.1 model output prepared for CMIP6 CMIP historical. Version 20191211. Earth System Grid Federation. https://doi.org/10.22033/ESGF/CMIP6.11485

Bader, D.C., Leung, R., Taylor, M., McCoy, R.B., 2020. E3SM-Project E3SM1.1ECA model output prepared for CMIP6 CMIP historical. Version 20200623.Earth System Grid
Federation.

https://doi.org/10.22033/ESGF/CMIP6.11486

Bentsen, M., Oliviè, D.J.L., Seland, Ø., et al., 2019. NCC NorESM2-MM model output prepared for CMIP6 CMIP historical. Version 20191108. Earth System Grid Federation. https://doi.org/10.22033/ESGF/CMIP6.8040

Bethke, I., Wang, Y., Counillon, F., et al., 2019. NCC NorCPM1 model output prepared for CMIP6 CMIP historical. Version 20200724. Earth System Grid Federation. https://doi.org/10.22033/ESGF/CMIP6.10894

Blázquez, J., Nuñez, M.N., 2013. Analysis of uncertainties in future climate projections for South America: comparison of WCRP-CMIP3 and WCRP-CMIP5 models. Climate Dynamics 41, 1039-1056. https://doi.org/10.1007/s00382012-1489-7

Boucher, O., Denvil, S., Levavasseur, G., et al., 2018. IPSL IPSL-CM6A-LR model output prepared for CMIP6 CMIP historical. Version 20180803. Earth System Grid Federation. https://doi.org/10.22033/ESGF/CMIP6.5195

Byun, Y.-H., Lim, Y.-J., Sung, H.M., et al., 2019. NIMS-KMA KACE1.0-G model output prepared for CMIP6 CMIP historical. Version 20190910. Earth System Grid Federation. https://doi.org/10.22033/ESGF/CMIP6.8378

Cao, J., Wang, B., 2019. NUIST NESMv3 model output prepared for CMIP6 CMIP historical. Version 20190630.Earth System Grid Federation. https://doi.org/10.22033/ESGF/CMIP6.8769

Carlson, D., Eyring, V., van der Wel, N., Langendijk, G., 2017. WCRP's Coupled Model Intercomparison Project: a remarkable contribution to climate science. European Geosciences Union [online]. Available: https://www.egu.eu/news/highlightarticles/586/wcrps-coupled-modelintercomparison-project-a-remarkablecontribution-to-climate-science/. Access: 11 feb. 2021.

Chen, C. T., Knutson, T., 2008. On the verification and comparison of extreme rainfall indices from climate models. Journal of Climate 21, 16051621. http://dx.doi.org/10.1175/2007JCLI1494.1

Chou, S.C., Lyra, A., Mourão, C., et al., 2014. Evaluation of the Eta Simulations Nested in Three Global Climate Models. American 
Journal of Climate Change 3, 438-454, 2014. http://dx.doi.org/10.4236/ajcc.2014.35039

Danabasoglu, G., 2019a. NCAR CESM2 model output prepared for CMIP6 CMIP historical. Version 20190401. Earth System Grid Federation.

https://doi.org/10.22033/ESGF/CMIP6.7627

Danabasoglu, G., 2019b. NCAR CESM2WACCM model output prepared for CMIP6 CMIP historical. Version 20190415. Earth System Grid Federation. https://doi.org/10.22033/ESGF/CMIP6.10071

Danabasoglu, G., 2019c. NCAR CESM2WACCM model output prepared for CMIP6 CMIP historical. Version 20190415. Earth System Grid Federation. https://doi.org/10.22033/ESGF/CMIP6.10071

Danabasoglu, G., 2019d. NCAR CESM2-FV2 model output prepared for CMIP6 CMIP historical. Version 20191120.Earth System Grid Federation. https://doi.org/10.22033/ESGF/CMIP6.11297

Danabasoglu, G., 2019e. NCAR CESM2WACCM-FV2 model output prepared for CMIP6 CMIP historical. Version 20191120. Earth System Grid Federation. https://doi.org/10.22033/ESGF/CMIP6.11298

Danek, C., Shi, X., Stepanek, C., et al., 2020. AWI AWI-ESM1.1LR model output prepared for CMIP6 CMIP historical. Version 20200212. Earth System Grid Federation. https://doi.org/10.22033/ESGF/CMIP6.9328

Dix, M., Bi, D., Dobrohotoff, P., et al., 2019. CSIRO-ARCCSS ACCESS-CM2 model output prepared for CMIP6 CMIP historical. Version 20191108. Earth System Grid Federation. https://doi.org/10.22033/ESGF/CMIP6.4271

Dufresne, J.L., Foujols, M.A., Denvil, S., et al., 2013. Climate change projections using the IPSL-CM5 Earth System Model: from CMIP3 to CMIP5. Climate Dynamics 40, 2123-2165. https://doi.org/10.1007/s00382-012-1636-1

EC-Earth Consortium (EC-Earth), 2019a. ECEarth-Consortium EC-Earth3-Veg model output prepared for CMIP6 CMIP historical. Version 20200225. Earth System Grid Federation.

https://doi.org/10.22033/ESGF/CMIP6.4706

EC-Earth Consortium (EC-Earth), 2019b. ECEarth-Consortium EC-Earth3 model output prepared for CMIP6 CMIP historical. Version
20200310. Earth System Grid Federation. https://doi.org/10.22033/ESGF/CMIP6.4700

EC-Earth Consortium (EC-Earth), 2020a. ECEarth-Consortium EC-Earth3-Veg-LR model output prepared for CMIP6 CMIP historical. Version 20200217. Earth System Grid Federation.

https://doi.org/10.22033/ESGF/CMIP6.4707

EC-Earth Consortium (EC-Earth), 2020b. ECEarth-Consortium EC-Earth3-AerChem model output prepared for CMIP6 CMIP historical. Version 20200624. Earth System Grid Federation.

https://doi.org/10.22033/ESGF/CMIP6.4701

Elguindi, N., Giorgi, F., Turuncoglu, U., 2014. Assessment of CMIP5 global model simulations over the subset of CORDEX domains used in the Phase I CREMA. Climatic Change 125, 7-21. https://doi.org/10.1007/s10584-013-0935-9

Eyring, V., Bony, S., Meehl, G.A., Senior, C.A., Stevens, B., Stouffer, R.J., Taylor, K.E., 2016. Overview of the Coupled Model Intercomparison Project Phase 6 (CMIP6) experimental design and organization, Geoscientific Model Development 9, 19371958. http://dx.doi.org/10.5194/gmd-9-1937$\underline{2016}$

Flato, G., Marotzke, J., Abiodun, B., et al., 2013. Evaluation of Climate Models. In: Climate Change 2013: The Physical Science Basis. Contribution of Working Group I to the Fifth Assessment Report of the Intergovernmental Panel on Climate Change [Stocker, T.F., D. Qin, G.-K. Plattner, M. Tignor, S.K. Allen, J. Boschung, A. Nauels, Y. Xia, V. Bex and P.M. Midgley (eds.)]. Cambridge University Press, Cambridge, United Kingdom and New York, NY, USA. [online] Available: https://www.ipcc.ch/report/ar5/wg1/. Access: 11 feb. 2021.

Freire, J.L., de Freitas, S.R., Coelho, C.A.dos.S., 2015. Calibração do modelo regional BRAMS para a previsão de eventos climáticos extremos. Revista Brasileira de Meteorologia 30(2), 158$170 . \quad$ http://dx.doi.org/10.1590/0102$\underline{778620140034}$

Giorgi, F., Mearns, L.O., 1999. Introduction to special section: regional climate modeling revisited. Journal of Geophysical Research 104(D6), 6335-6352. 
Gulizia, C., Camilloni, I., 2014. Comparative analysis of the ability of a set of CMIP3 and CMIP5 global climate models to represent precipitation in South America. International Journal of Climatology 35(4), 583-595. https://doi.org/10.1002/joc.4005

Gutowski Jr., W. J., Giorgi, F., Timbal, B., et al., 2016 WCRP COordinated Regional Downscaling EXperiment (CORDEX): a diagnostic MIP for CMIP6. Geoscientific Model Development 9, 4087-4095, https://doi.org/10.5194/gmd-9-4087-2016

Hersbach, H., Dee, D., 2016. ERA5 reanalysis is in production. ECMWF Newsletter [online] 147, 7.

Available: https://www.ecmwf.int/en/newsletter/147/news lera5-reanalysis-production. Access: $11 \mathrm{feb}$. 2021.

Hinkle, D.E., Wiersma, W., Jurs, S. G., 2003. Applied Statistics for the Behavioral Sciences. 5th ed. Boston: Houghton Mifflin, 756 p.

Huang, W., 2019. THU CIESM model output prepared for CMIP6 CMIP historical. Version 20200417. Earth System Grid Federation. https://doi.org/10.22033/ESGF/CMIP6.8843

Huffman, G. J., Adler, R. F., Morrissey, M. M., Bolvin, D.T., Curtis, S., Joyce, R., McGavock, B., Susskind, J., 2001. Global Precipitation at One-Degree Daily Resolution from Multisatellite Observations. Journal of Hydrometeorology 2, 36-50. http://dx.doi.org/10.1175/15257541(2001)002<0036:GPAODD>2.0.CO;2

Jones, P. W. 1999. First and second-order conservative remapping schemes for grids in spherical coordinates. Monthly Weather Review, 127, 2204-221. http://dx.doi.org/10.1175/15200493(1999)127\%3C2204:FASOCR\%3E2.0.C $\underline{0 ; 2}$

Jungclaus, J., Bittner, M., Wieners, K.H., 2019. MPI-M MPI-ESM1.2-HR model output prepared for CMIP6 CMIP historical. Version 20190710. Earth System Grid Federation. https://doi.org/10.22033/ESGF/CMIP6.6594

Krasting, J.P., John, J.G., Blanton, C., et al., 2018. NOAA-GFDL GFDL-ESM4 model output prepared for CMIP6 CMIP historical. Version 20190726. Earth System Grid Federation. https://doi.org/10.22033/ESGF/CMIP6.8597
Lee, W.-L., Liang, H.-C., 2020. AS-RCEC TaiESM1.0 model output prepared for CMIP6 CMIP historical. Version 20200623. Earth System Grid Federation. https://doi.org/10.22033/ESGF/CMIP6.9755

Li, L., 2019. CAS FGOALS-g3 model output prepared for CMIP6 CMIP historical. Version 20190818. Earth System Grid Federation. https://doi.org/10.22033/ESGF/CMIP6.3356

Llopart, M., Reboita, M.S., da Rocha, R.P., 2020. Assessment of multi-model climate projections of water resources over South America CORDEX domain. Climate Dynamics 54, 99116. https://doi.org/10.1007/s00382-01904990-z

Lovato, T., Peano, D., 2020. CMCC CMCC-CM2SR5 model output prepared for CMIP6 CMIP historical. Version 20200616. Earth System Grid Federation. https://doi.org/10.22033/ESGF/CMIP6.3825

Marrafon, V., Reboita, M.S., 2020. Características da precipitação na América do Sul reveladas através de índices climáticos. Revista Brasileira de Climatologia 26(16) 663. http://dx.doi.org/10.5380/abclima.v26i0.7218

Metsalu, T., Vilo, J. 2015. ClustVis: a web tool for visualizing clustering of multivariate data using Principal Component Analysis and heatmap. Nucleic Acids Research 43(W1), W566-W570. https://doi.org/10.1093/nar/gkv468

NASA Goddard Institute for Space Studies, 2018. NASA-GISS GISS-E2.1G model output prepared for CMIP6 CMIP historical. Version 20180827. Earth System Grid Federation. https://doi.org/10.22033/ESGF/CMIP6.7127

NASA Goddard Institute for Space Studies, 2019. NASA-GISS GISS-E2.1H model output prepared for CMIP6 CMIP historical. Version 20190403. Earth System Grid Federation. https://doi.org/10.22033/ESGF/CMIP6.7128

Neubauer, D., Ferrachat, S., Siegenthaler-Le Drian, C., al., 2019. HAMMOZ-Consortium MPIESM1.2-HAM model output prepared for CMIP6 CMIP historical. Version 20190627.Earth System Grid Federation. https://doi.org/10.22033/ESGF/CMIP6.5016

Park, S., Shin, J., 2019. SNU SAM0-UNICON model output prepared for CMIP6 CMIP historical. Version 20190323. Earth System Grid Federation. https://doi.org/10.22033/ESGF/CMIP6.7789 
Pedro, D.F.P., Freitas, A.C.V., Belotti, F.M., 2020. A influência da Zona de Convergência do Atlântico Sul (ZCAS) na ocorrência de deslizamentos de massa em Belo Horizonte e cidades vizinhas. Revista Brasileira de Climatologia 17(16), 635-659. http://dx.doi.org/10.5380/abclima.v27i0.70352

Raghavan, K., Panickal, S., 2019. CCCR-IITM IITM-ESM model output prepared for CMIP6 CMIP historical. Version 20191226. Earth System Grid Federation. https://doi.org/10.22033/ESGF/CMIP6.3708

Reboita, M. S. Gan, M.A., da Rocha, R.P., Ambrizzi, T., 2010. Regimes de precipitação na América do Sul: Uma revisão bibliográfica. Revista Brasileira de Meteorologia, 25(2), 185$204 . \quad$ https://doi.org/10.1590/S01027786201000020000

Reboita, M.S., Dias, C.G., Dutra, L.M.M., da Rocha, R.P., Llopart, M., 2018. Previsão Climática Sazonal para o Brasil Obtida Através de Modelos Climáticos Globais e Regional. Revista Brasileira de Meteorologia 33(2), 207224. https://doi.org/10.1590/0102-7786332001

Rong, X., 2019. CAMS CAMS_CSM1.0 model output prepared for CMIP6 CMIP historical. Version 20190708. Earth System Grid Federation.

https://doi.org/10.22033/ESGF/CMIP6.9754

Santos, DF.dos., Martins, F.B., Torres, R.R., 2017. Impacts of climate projections on water balance and implications on olive crop in Minas Gerais. Revista Brasileira de Engenharia Agrícola e Ambiental 21(2), 77-82. http://dx.doi.org/10.1590/18071929/agriambi.v21n2p77-82

Scoccimarro, E., Bellucci, A., Peano, D., 2020. CMCC CMCC-CM2-HR4 model output prepared for CMIP6 CMIP historical. Version 20200904. Earth System Grid Federation. https://doi.org/10.22033/ESGF/CMIP6.3823

Seland, Ø., Bentsen, M., Oliviè, D.J.L., et al., 2019. NCC NorESM2-LM model output prepared for CMIP6 CMIP historical. Version 20190815. Earth System Grid Federation. https://doi.org/10.22033/ESGF/CMIP6.8036

Semmler, T., Danilov, S., Rackow, T., et al., 2018. AWI AWI-CM1.1MR model output prepared for CMIP6 CMIP historical. Version 20200511. Earth System Grid Federation. https://doi.org/10.22033/ESGF/CMIP6.2686
Silva, J.P.R., Reboita, M.S., Escobar, G.C.J., 2019. Caracterização da Zona De Convergência do Atlântico Sul em Campos Atmosféricos Recentes. Revista Brasileira de Climatologia 25(15), 355-377. http://dx.doi.org/10.5380/abclima.v25i0.64101

Solman, S.A., Sanchez, E., Samuelsson, P., et al., 2013. Evaluation of an ensemble of regional climate model simulations over South America driven by the ERA-Interim reanalysis: model performance and uncertainties. Climate Dynamics 41, 1139-1157. http://dx.doi.org/10.1007/s00382-013-1667-2

Song, Zhenya, et al., 2019. FIO-QLNM FIOESM2.0 model output prepared for CMIP6 CMIP historical. Version 20191209. Earth System Grid Federation. https://doi.org/10.22033/ESGF/CMIP6.9199

Stouffer, R., 2019. UA MCM-UA-1-0 model output prepared for CMIP6 CMIP historical. Version 20191017. Earth System Grid Federation. https://doi.org/10.22033/ESGF/CMIP6.8888

Swart, N.C., Cole, J.N.S., Kharin, V.V., et al., 2019. CCCma CanESM5 model output prepared for CMIP6 CMIP historical. Version 20190429. Earth System Grid Federation. https://doi.org/10.22033/ESGF/CMIP6.3610

Tatebe, H., Watanabe, M., 2018. MIROC MIROC6 model output prepared for CMIP6 CMIP historical. Version 20181212. Earth System Grid Federation. https://doi.org/10.22033/ESGF/CMIP6.5603

Tian, B., Dong, X., 2020. The Double- ITCZ Bias in CMIP3, CMIP5, and CMIP6 Models Based on Annual Mean Precipitation. Geophysical Research Letters 47, 1-11. https://doi.org/10.1029/2020GL087232

Torres, R.R., Marengo, J.A., 2013. Climate change hotspots over South America: from CMIP3 to CMIP5 multi-model datasets. Theoretical and Applied Climatology volume 117, 579-587. http://dx.doi.org/10.1007/s00704-013-1030-x

Vasconcellos, F.C., Deng, Y., Zhang, H., Martins, G., 2020. Austral summer precipitation biases over tropical South America in five CMIP5 earth system models. International Journal of Climatology $\quad 40, \quad 6506-6525$. http://dx.doi.org/10.1002/joc.6595.

Volodin, E., Mortikov, E., Gritsun, A., et al., 2019a. INM INM-CM4-8 model output 
prepared for CMIP6 CMIP historical. Version 20190530. Earth System Grid Federation. https://doi.org/10.22033/ESGF/CMIP6.5069

Volodin, E., Mortikov, E., Gritsun, A., et al., 2019b. INM INM-CM5-0 model output prepared for CMIP6 CMIP historical. Version 20190610. Earth System Grid Federation. https://doi.org/10.22033/ESGF/CMIP6.5070

Wieners, K.-H., Giorgetta, M., Jungclaus, J., et al., 2019. MPI-M MPI-ESM1.2-LR model output prepared for CMIP6 CMIP historical. Version 20190710. Earth System Grid Federation. https://doi.org/10.22033/ESGF/CMIP6.6595

Willmott, C. J., Robeson, S. M., Matsuura, K., 2011. A refined index of model performance. International Journal of Climatology 32(13), 2088-2094. http://dx.doi.org/10.1002/joc.2419

Wu, T., Chu, M., Dong, M., et al., 2018. BCC BCC-CSM2MR model output prepared for CMIP6 CMIP historical. Version 20181126. Earth System Grid Federation. https://doi.org/10.22033/ESGF/CMIP6.2948

Wu, T., Lu, Y., Fang, Y., et al., 2019. The Beijing Climate Center Climate System Model (BCCCSM): the main progress from CMIP5 to CMIP6. Geoscientific Model Development 12(4), 1573-1600. https://doi.org/10.5194/gmd$\underline{12-1573-2019}$
Yi, M., 2019. A complete guide to heatmaps. Chartio [online]. Available: https://chartio.com/learn/charts/heatmapcomplete-guide/ .Access: 25 feb. 2021.

Yu, Yongqiang, 2019. CAS FGOALS-f3-L model output prepared for CMIP6 CMIP historical. Version 20190927.Earth System Grid Federation.

https://doi.org/10.22033/ESGF/CMIP6.3355

Yukimoto, S., Koshiro, T., Kawai, H., et al., 2019. MRI MRI-ESM2.0 model output prepared for CMIP6 CMIP historical. Version 20190222. Earth System Grid Federation. https://doi.org/10.22033/ESGF/CMIP6.6842

Zhang, J., Wu, T., Shi, X., et al., 2018. BCC BCCESM1 model output prepared for CMIP6 CMIP historical. Version 20181214. Earth System Grid Federation. https://doi.org/10.22033/ESGF/CMIP6.2949

Ziehn, T., Chamberlain, M., Lenton, A., et al., 2019. CSIRO ACCESS-ESM1.5 model output prepared for CMIP6 CMIP historical. Version 20191115.Earth System Grid Federation. https://doi.org/10.22033/ESGF/CMIP6.4272 